\title{
Mechanical unzipping of DNA molecules in parallel using nanophotonic tweezers (Withdrawal Notice)
}

Fan Ye, James Inman, Michelle Wang

Fan Ye, James T. Inman, Michelle D. Wang, "Mechanical unzipping of DNA molecules in parallel using nanophotonic tweezers (Withdrawal Notice)," Proc. SPIE 11463, Optical Trapping and Optical Micromanipulation XVII, 1146305 (2 February 2021); doi: 10.1117/12.2570629

SPIE. Event: SPIE Nanoscience + Engineering, 2020, Online Only 


\title{
Mechanical unzipping of DNA molecules in parallel using nanophotonic tweezers (Withdrawal Notice)
}

\author{
Fan $\mathrm{Ye}^{1,2}$, James T. Inman ${ }^{1,2}$, Michelle D. Wang ${ }^{1,2}$ \\ 'Cornell Univ. (United States) \\ ${ }^{2}$ Howard Hughes Medical Institute (United States)
}

Proceedings Volume 11463, Optical Trapping and Optical Micromanipulation XVII; 1146305 (2020)

https://doi.org/10.1117/12.2570629

Event: SPIE Nanoscience + Engineering, 2020, Online Only

Online Publication Date: 10 August 2020

Withdrawn from Publication: 2 February 2021

Publisher's Note: This presentation, originally published on 10 August 2020, was withdrawn per author request. 